\title{
Strategi Pemasaran Produk Fulprotek PT Asuransi Takaful Keluarga dan Bank Muamalat Indonesia
}

\author{
Putri Ayuni ${ }^{1}$, Nuri Aslami ${ }^{2}$ \\ Universitas Islam Negeri Sumatera Utara \\ pa6851@gmail.com
}

\begin{abstract}
Marketing is one of the economic sciences that has long developed, and until now marketing greatly affects the success of a company to be able to survive in market share. Therefore the company must carry out a marketing mix which also has an influence to determine the success or failure of marketing its products. If the marketing mix implemented by the company is able to market its products well, this will affect the company's goals.
\end{abstract}

\section{Keywords: Marketing. Economy, Fullprotect}

\begin{abstract}
ABSTRAK
Pemasaran merupakan salah satu ilmu ekonomi yang telah lama berkembang, dan sampai pada saat ini pemasaran sangat mempengaruhi keberhasilan suatu perusahaan untuk bisa bertahan di dalam pangsa pasar. Oleh karena itu perusahaan harus melakukan bauran pemasaran yang juga mempunyai pengaruh untuk menentukan berhasil tidaknya dalam memasarkan produknya. Apabila bauran pemasaran yang di laksanakan perusahaan tersebut mampu memasarkan produknya dengan baik, hal ini akan berpengaruh terhadap tujuan perusahaan.
\end{abstract}

\section{Kata Kunci: Pemasaran. Ekonomi, Fullprotek}

\section{Pendahuluan}

Kehidupan manusia yang senantiasa berubah dari waktu ke waktu membawa konsekuensi perubahan tuntutan dalam kehiupannya. Perubahan kehidupan manusia dapat terjadi karena perubahan umur, perubahan pendidikan, perubahan penghasilan, maupun perubahan sosial sehingga mau tidak mau harus merubah pola kehidupannya yang disesuaikan dengan kondisi yang melingkupinya.

Kebutuhan jasa perasuransian makin dirasakan, baik oleh perorangan maupun dunia usaha di Indonesia. Asuransi merupakan sarana financial dalam tata kehidupan rumah tangga baik dalam menghadapi resiko yang mendasar seperti: Resiko kematian, atau dalam menghadapi resiko atas harta benda yang dimiliki. 


\section{VISA: Journal of Visions and Ideas}

\section{Vol 1 No 3 (2021) 248-260 E-ISSN 2809-2058 P-ISSN 2809-2643 DOI: 47467/visa.v1i3.794}

Demikian pula dunia usaha dalam menjalankan kegiatannya menghadapi berbagai resiko yang mungkin dapat mengganggu kesinambungan usaha.

Walaupun banyak metode untuk menangani resiko, namun asuransi merupakan metode yang banyak dipakai. Asuransi menjanjikan perlindungan kepada pihak tertanggung terhadap resiko yang di hadapi perorangan maupun resiko yang dihadapi perusahaan, semakin hari produk asuransi yang dipasarkan semakin variatif dan sudah di modifikasi dengan jenis produk keuangan lainnya, salah satunya adalah produk asuransi yang di kombinasikan dengan produk perbankan.

Sudah seharusnya industri perbankan dan asuransi lebih memperkuat dan memaksimalkan pendayagunaan dana masyarakat. Di dunia perbankan maupun asuransi istilah Bancassurance (pemasaran produk asuransi melalui bank) bukanlah suatu hal yang baru. Istilah ini telah di pakai oleh kedua lembaga keuangan itu dalam menggembangkan jaringan bisnis yang di yakini memiliki prospek sangat cerah di masa mendatang. Apalagi konsep ini merupakan konsep perpaduan antara produk jasa perbankan dengan produk asuransi yang menawarkan perlindungan (proteksi).

Pemasaran merupakan salah satu ilmu ekonomi yang telah lama berkembang, dan sampai pada saat ini pemasaran sangat mempengaruhi keberhasilan suatu perusahaan untuk bisa bertahan di dalam pangsa pasar. Oleh karena itu perusahaan harus melakukan bauran pemasaran yang juga mempunyai pengaruh untuk menentukan berhasil tidaknya dalam memasarkan produknya. Apabila bauran pemasaran yang di laksanakan perusahaan tersebut mampu memasarkan produknya dengan baik, hal ini akan berpengaruh terhadap tujuan perusahaan.

Salah satu strategi yang berperan penting adalah kebijakan harga, dimana dengan penetapan harga yang tepat sesuai dengan target marketnya, diharapkan tingkat penjualan produk perusahaan dapat meningkat dan bersaing dengan produk lain yang sejenis. Usaha untuk mempertahankan atau bahkan meningkatkan volume penjualan ini dapat juga di tempuh perusahaan dengan cara melakukan promosi. Tujuan dari promosi adalah menumbuhkan rangsangan pada orang terhadap produk yang dipasarkan.

Maka pemahaman tentang produk menjadi sesuatu yang sangat penting dalam dunia usaha Asuransi Syariah. Asuransi sebagai lembaga keuangan perlu mengkomunikasikan setiap produk yang mereka tawarkan. Hal ini dilakukan agar masyarakat mengetahui dan memiliki minat membeli manfaat dari produk asuransi yang ditawarkan sesuai dengan kebutuhan dan keinginannya. Banyak perusahaan asuransi yang menawarkan produkya, baik produk baru atau pengembangan dari produk lama.

Diantara mereka ada yang gagal dan tidak sukses dalam merebut kepuasan konsumen. Hal ini disebabkan karena pembeli (buyer's market) yang selalu 


\section{VISA: Journal of Visions and Ideas}

\section{Vol 1 No 3 (2021) 248-260 E-ISSN 2809-2058 P-ISSN 2809-2643 DOI: 47467/visa.v1i3.794}

berubah-ubah. Sebagai perusahaan asuransi yang murni syariah, Perusahaan Asuransi Takaful Keluarga harus mempunyai strategi tersendiri dalam mengembangkan dan memasarkan produknya. Persoalannya adalah bagaimana membuat produk asuransi yang baik dan berkualitas yang nantinya akan dapat menarik minat nasabah dalam membeli manfaat dari produk asuransi tersebut, dan bagaimana produk Asuransi Syariah tersebut dapat di pasarkan kepada masyarakat, terutama kepada masyarakat yang ber agama Islam dan starategi apa yang lebih tepat digunakan dalam pemasaran tersebut.

Saat ini, pemasaran asuransi dengan menggunakan jasa perbankan me rupakan hal yang tidak asing lagi. Karena produk-produk yang ditawarkan sangat beraneka macam untuk seluruh kebutuhan yang berkaitan dengan kepentingan industrinya. Salah satu antaranya yaitu kartu fulPROTEK milik PT Asuransi Takaful Keluarga (ATK). Produk ini merupakan sebuah produk kolaborasi dari Takaful Indonesia dengan Bank Muamalat.

Produk ini memberikan perlindungan sepenuhnya melalui Investasi murni syariah. fulPROTEK adalah terobosan baru produk bancassurance, me nawarkan berbagai kelebihan meliputi kartu multiguna yang berfungsi sebagai kartu asuransi, ATM dan debit, bedanya fulPROTEK merupakan kartu investasi berasuransi yang dikelola secara syariah dengan bagi hasil menguntungkan. Keberadaan produk Asuransi Syariah selain karena tuntutan pasar juga di karenakan keberadaan suatu produk di perlukan dalam rangka menjaga komitmen terhadap prinsip-prinsip syariah terutama kemaslahatan ummat dan rahmatan lil alamin. Kondisi ini menunjukkan bahwa selain karena orientasi bisnis, Asuransi Syariah juga berorientasi pada Syiar Islam. Hal inilah yang menjadikan Asuransi Syariah dituntut lebih aktif, kreatif dan inovatif terhadap berbagai perkembangan di dalam kehidupan masyarakat.

Perkembangan Asuransi Syariah dan banyaknya masalah masyarakat yang ditemui, akan berdampak semakin beragam produk yang ditawarkan kepada masyarakat. Produk Asuransi Syariah merupakan representasi dari kondisi "permintaan" masyarakat akan keberadaan suatu produk. Maka dengan keberadaan ini perlu dukungan dari berbagai elemen masyarakat untuk menjadikan posisi Asuransi Syariah dengan dukungan produkproduknya semakin berarti dalam pembangunan.

\section{Strategi Pemasaran}

Strategi berasal dari kata Yunani Strategeta $($ Stratos $=$ militer, dan ag = memimpin), artinya seni atau ilmu untuk menjadi seorang Jenderal. Konsep ini relevan dengan situasi pada zaman dahulu yang sering diwarnai perang, dimana jenderal dibutuhkan untuk memimpin suatu angkatan perang agar dapat selalu memenangkan perang. 


\section{VISA: Journal of Visions and Ideas}

\section{Vol 1 No 3 (2021) 248-260 E-ISSN 2809-2058 P-ISSN 2809-2643 DOI: 47467/visa.v1i3.794}

Bisnis adalah perang, karena pada dasarnya menjalankan bisnis adalah menjalankan strategi bertahan, menyerang dan menaklukan musuh. Itulah sebabnya, banyak sekali falsafah perang yang kemudian di terap kan dalam strategi pemasaran.

Demikian halnya dengan teori pemasaran. Pemasaran merupakan fungsi bisnis yang mengidentifikasikan keinginan dan kebutuhan yang belum terpenuhi saat sekarang, mengukur seberapa besarnya kebutuhan tersebut, menentukan sasaran mana yang paling baik untuk dilayani organisasi serta mencari program pelayanan yang tepat untuk mampu melayani keinginan pasar. Jadi pemasaran merupakan media penghubung antara kebutuhan nasabah potensial dengan organisasi atau manajemen sebagai produsen produk dan jasa perusahaan.

Seperti diketahui, tidak seorangpun terutama ahli-ahli pemasaran yang tidak memandang penting kehadiran sebuah sistem pemasaran di dalam setiap perusahaan. Termasuk di dalamnya perusahaan asuransi baik itu konvensional maupun asuransi syariah.

Menurut M. Syakir Sula mendefinisikan pemasaran sebagai sebuah disiplin bisnis strategis yang mengarahkan proses penciptaan, penawaran, dan perubahan values dari satu inisiator kepada stakeholders-nya.

Kotler mendefinisikan pemasaran adalah suatu proses sosial dan manajerial yang di dalamnya terdiri dari individu dan kelompok dalam mendapatkan apa yang mereka butuhkan dan inginkan dengan menciptakan, menawarkan, dan mempertukarkan produk yang bernilai dengan pihak lain.

Menurut definisi dari AMA (American Marketing Association) Pemasaran memiliki dua hal. Pertama, pemasaran merupakan filosofi, sikap, perspektif atau orientasi manajemen yang menekankan pada kepuasan konsumen. Kedua, pemasaran adalah sekumpulan aktivitas yang digunakan untuk mengimplementasikan filosofi ini. Jadi pemasaran merupakan suatu proses perencanaan dan menjalankan konsep, harga, promosi, dan distribusi sejumlah ide, barang, dan jasa untuk menciptakan pertukaran yang mampu memuaskan tujuan individu dan organisasi.

Pemasaran adalah sebuah disiplin bisnis strategis yang mengarah kan proses penciptaan, penawaran, dan perubahan value dari suatu inisiator kepada stakeholder-nya, yang dalam keseluruhan prosesnya sesuai dengan akad dan prinsip-prinsip muamalah dalam Islam.

Strategi adalah rencana cermat tentang suatu kegiatan guna meraih suatu target atau sasaran. Sedang pemasaran adalah suatu sistem keseluruhan dari kegiatan-kegiatan usaha yang saling berkaitan antara satu dengan yang lain bertujuan untuk merencanakan, menentukan harga, melakukan promosi serta mendistribusikan barang dan jasa untuk memuas kan kebutuhan pembeli yang ada khususnya kepada pembeli potensial. 


\section{VISA: Journal of Visions and Ideas}

\section{Vol 1 No 3 (2021) 248-260 E-ISSN 2809-2058 P-ISSN 2809-2643 DOI: 47467/visa.v1i3.794}

Adapun tujuan marketing atau pemasaran adalah untuk memahami keinginan dan kebutuhan konsumen agar produk atau jasa sesuai bagi konsumen sehingga produk-produk atau jasa tesebut dapat terjual dengan sendirinya. Jika dewasa ini pasar barang dan jasa merupakan pasar pembeli (buyer's market), dimana para pemakai dapat menentukan harga beli dikerenakan barang dan jasa sangat melimpah, sehingga penjual dapat menentukan harga produk (seller's merket) atau dikatakan sebagai pasar penjual.

Menurut perspektif syariah Pemasaran adalah segala aktivitas yang dijalankan dalam kegiatan bisnis berbentuk kegiatan penciptaan nilai (value creating activities) yang memungkinkan siapapun yang melakukannya bertumbuh serta mendayagunakan kemanfaatannya yang dilandasi atas kejujuran, keadilan, keterbukaan dan keikhlasan sesuai dengan proses yang berprinsip pada akad bermuamalah islami atau perjanjian transaksi bisnis dalam islam.

Pemasaran dalam fiqih Islam disebut wakalah atau perwakilan. Wakalah atau wikalah yang berarti penyerahan, pendelegasian, atau pemberian mandat. Wakalah dapat juga didefinisikan sebagai penyerahan dari seseorang (pihak pertama/pemberi perwakilan) apa yang boleh dilakukan sendiri dan dapat diwakilkannya kepada yang lain (pihak kedua) untuk me lakukannya semasa ia (pihak prtama) masih hidup.

Dengan demikian orientasi produsen dalam buyer's market adalah pada keinginan dan kebutuhan konsumen. Untuk mengarah pada tujuan tersebut, maka kegiatan ataupun proses pertukaran itu harus dapat dikelola dengan baik oleh manusia dan organisasinya agar dapat menghasilkan pendapatan bagi mereka sendiri serta kepuasan bagi pihak lain.

Dalam kegiatannya dengan pengelolaan dari proses pertukaran itu, strategi pemasaran akan dapat digunakan sebagai alat bantu agar dapat mem pengaruhi tingkat, pemilihan waktu (timeing) dan sifat permintaan sedemikian rupa sehingga membantu organisasi dalam mencapai tujuan nya.

Dari paparan diatas, maka strategi pemasaran sendiri dapat diartikan sebagai seleksi atas pasar sasaran, menentukan posisi bersaing dan pengembangan suatu bauran pemasaran yang efektif untuk mencapai dan melayani klien-klien yang telah terpilih. 0 Dari definisi tersebut, dalam memasarkan produk atau jasa yang dihasilkan perusahaan terlebih dahulu harus menentukan siapa yang akan menjadi pasar sasaran (target market), kemudian di ikuti dengan pengembangan strategi penentuan posisi bersaing dengan perusahaan-perusahaan lain yang telah memutuskan pasar yang sama sebagai target sasarannya. Disamping itu, perusahaan harus juga selalu mengembangkan bauran pemasaran yang terdiri dari produk, harga, promosi dan distribusi sehingga dapat bersaing dengan perusahaan lain.

Setiap perusahaan mempunyai tujuan untuk dapat tetap hidup dan ber kembang, tujuan tersebut hanya dapat dicapai melalui usaha mempertahankan dan meningkatkan penjualannya, melalui usaha mencari dan membina langganan, serta 


\section{VISA: Journal of Visions and Ideas}

\section{Vol 1 No 3 (2021) 248-260 E-ISSN 2809-2058 P-ISSN 2809-2643 DOI: 47467/visa.v1i3.794}

usaha menguasai pasar. Tujuan ini hanya dapat dicapai apabila bagian pemasaran perusahaan melakukan strategi yang mantap untuk dapat menggunakan kesempatan atau peluang yang ada dalam pemasaran, sehingga posisi atau kedudukan perusahaan dipasar dapat dipertahankan dan sekaligus ditingkatkan.

Oleh karena itu strategi pemasaran mempunyai peranan yang sangat penting untuk keberhasilan usaha perusahaan umumnya dan pemasaran khususnya. Di samping itu, strategi pemasaran yang ditetapkan harus ditinjau dan dikembang kan sesuai dengan perkembangan pasar dan lingkungan pasar tersebut. Dengan demikian, strategi pemasaran harus dapat memberi gambaran yang jelas dan terarah tentang apa yang akan dilakukan perusahaan dalam menggunakan setiap kesempatan atau peluang pada beberapa pasar sasaran.

Strategi Pemasaran Produk fulPROTEK Dewasa ini perusahaan-perusahaan jasa asuransi menerapkan strategi baru dalam memasarkan produk-produknya karena banyaknya persaingan yang ketat dalam setiap perusahaan, juga mempunyai tujuan agar dapat tetap bertahan hidup, berkembang dan diminati oleh konsumen.

Dalam memasarkan suatu produk, hal yang sangat penting untuk diketahui adalah mengenai bauran pemasaran (marketing mix). Istilah bauran pemasaran mengacu pada paduan strategi produk, distribusi, promosi, dan penentuan harga yang bersifat unik yang dirancang untuk menghasilkan pertukaran yang saling memuaskan dengan pasar yang dituju. Bauran pemasaran terdiri atas 4P yaitu: Produk (Product), Harga (Price), Tempat (Place), dan Promosi (Promotion).

\section{Produk (Product)}

Biasanya bauran pemasaran dimulai dengan produk "P". Inti dari bauran pemasaran, yang merupakan langkah awalnya adalah penawaran produk dan strategi produk. Sangat sulit untuk mendisain suatu strategi distribusi, memutuskan kampanye promosi, atau menentukan harga tanpa mengenali produk yang akan dipasarkan. Produk tidak hanya meliputi unit fisiknya saja tetapi juga kemasan, garansi, merek, nama baik perusahaan, nilai kepuasan dan masih banyak lagi faktor lainnya.

Hal inilah yang dijadikan dasar Perusahaan Asuransi Takaful Keluarga dalam membuat suatu produk, selain produk yang dihasilkan harus sesuai dengan keinginan dan kebutuhan pembeli (nasabah) produk tersebut juga mencerminkan kombinasi antara barang dan jasa yang ditawarkan. Strategi pemasaran produk fulPROTEK adalah dengan memberi kan kemudahan dan keuntungan yang dapat diperoleh oleh nasabah dari produk fulPROTEK tesebut antara lain:

a. Merupakan kartu multiguna yang berfungsi sebagai kartu asuransi, ATM, dan debit.

b. Memberikan kemudahan dalam bertransaksi dengan tarik tunai bebas biaya di lebih dari 8.888 ATM Muamalat, BCA, dan ATM bersama di seluruh Indonesia. 


\section{VISA: Journal of Visions and Ideas}

\section{Vol 1 No 3 (2021) 248-260 E-ISSN 2809-2058 P-ISSN 2809-2643 DOI: 47467/visa.v1i3.794}

c. Akses debit di lebih dari 18.000 marchant.

d. Kemudahan pembayaran premi melalui automatic debit dan phonebanking.

e. Saldo dapat ditambah setiap saat melalui 1.200 kantor pos online (SOPP), Bank Muamalat, dan IZI UANG Agen T3 (TE TRI) di seluruh Indonesia.

f. Saldo investasi dapat diketahui kapan setiap saat melalui phonebanking, ATM, atau SMS Banking.

g. Bagi hasil halal dan kompetitif dari investasi murni syariah.

h. Manfaat asuransi lengkap meliputi: santunan meninggal dunia, cacat tetap total atau sebagian karena kecelakaan, penggantian biaya perawatan dan pengobatan karena kecelakaan.

i. Simple Underwriting dan Instant Cover.

j. Bagi hasil dari surplus underwriting (jika ada).

k. Proteksi berlaku di seluruh dunia.

\section{Harga (Price)}

Menurut bayangan orang-orang, harga adalah uang yang dibayarkan atas suatu barang atau layanan yang diterima. Memang daftar hargalah yang sering menjadi pusat perhatian saat membeli barang atau layanan. Namun yang dinamakan harga adalah lebih luas dari sekedar daftar harga. Menurut Kotler harga adalah nilai yang diperuntukkan konsumen untuk suatu manfaat atas pengkonsumsian, penggunaan, atau kepemilikkan barang atau jasa.

Strategi penentuan harga sangat signifikan dalam memberikan nilai kepada konsumen dan mempengaruhi image produk, serta keputusan konsumen untuk membeli. Penetapan harga juga berhubungan dengan pendapatan dan turut mempengaruhi suplai atau marketing chanels. Akan tetapi yang paling penting dalam penetapan harga adalah harus konsisten dengan strategi pemasaran secara keseluruhan.

Harga adalah apa yang harus diberikan oleh pembeli untuk mendapatkan suatu produk. Harga sering merupakan elemen yang paling fleksibel di antara keempat elemen bauran pemasaran yaitu elemen yang paling cepat berubah. Harga merupakan senjata persaingan yang penting dan bahkan sangat penting bagi organisasi karena harga dikalikan dengan jumlah unit produk yang terjual sama dengan total penerima perusahaan.

Produk fulPROTEK merupakan produk co-branding antara PT. Asuransi Takaful Keluarga dan PT. Bank Muamalat Indonesia Tbk. Dimana pada produk tersebut terbagi menjadi 3 pilihan seri, yang masing-masing me miliki ketentuan harga dan manfaat yang akan diperoleh bagi calon nasabahnya antara lain sebagai berikut: 


\section{VISA: Journal of Visions and Ideas \\ Vol 1 No 3 (2021) 248-260 E-ISSN 2809-2058 P-ISSN 2809-2643 DOI: 47467/visa.v1i3.794}

1) Seri 175, dengan harga perdana Rp. 175.000,- manfaat yang akan didapat :

a) Saldo awal tabungan Rp. 100.000,-

b) Bila meninggal karena kecelakaan Rp. 25.000.000,-

c) Cacat tetap karena kecelakaan, makimum Rp. 5.000.000,-

d) Biaya perawatan karena kecelakaan, maksimum Rp. 1.250.000,- perkecelakaan

e) Meninggal dunia biasa (bukan akibat kecelakaan) Rp. 5.000.000,-

2) Seri 275, dengan harga perdana Rp. 275.000,- manfaat yang akan didapat :

a) Saldo awal tabungan Rp. 100.000,-

b) Bila meninggal karena kecelakaan Rp. 100.000.000,-

c) Cacat tetap karena kecelakaan, makimum Rp. 8.000.000,-

d) Biaya perawatan karena kecelakaan, maksimum Rp. 5.000.000,- perkecelakaan

e) Meninggal dunia biasa (bukan akibat kecelakaan) Rp. 8.000.000,-

3) Seri 750, dengan harga perdana Rp. 750.000,- manfaat yang akan didapat :

a) Saldo awal tabungan Rp. 500.000,-

b) Bila meninggal karena kecelakaan Rp. 100.000.000,-

c) Cacat tetap karena kecelakaan, makimum Rp. 20.000.000,-

d) Biaya perawatan karena kecelakaan, maksimum Rp. 5.000.000,- perkecelakaan

e) Meninggal dunia biasa (bukan akibat kecelakaan) Rp. 20.000.000,-

Dalam setiap penjualannya komisi yang akan diterima oleh seorang agen yaitu sebesar :

Seri 175 komisi agen sebesar Rp. 12.500,- per kartu

Seri 275 komisi agen sebesar Rp. 30.000,- per kartu

Seri 750 komisi agen sebesar Rp. 70.000,- per kartu

\section{Tempat (Place)}

Berbicara masalah tempat berarti pembahasannya tentang dimana PT. Asuransi Takaful Keluarga sebagai perusahaan yang bergerak dibidang jasa, dalam menentukan tempat dimana perusahaan harus bermarkas tentunya memperhatikan saluran distribusi pemasaran produknya. 


\section{VISA: Journal of Visions and Ideas}

\section{Vol 1 No 3 (2021) 248-260 E-ISSN 2809-2058 P-ISSN 2809-2643 \\ DOI: 47467/visa.v1i3.794}

Dalam pemasaran produk fulPROTEK, PT Asuransi Takaful Keluarga selain bekerjasama dengan Bank Muamalat Indonesia juga masih menggunakan tenaga agen (financial consultant) dan juga 3 (tiga) distribusi chanel produk fulPROTEK yaitu diantaranya:

1) BAZNAS

2) PT. POS

3) KOPKAR (Koprasi Karyawan), dan AO (Alliance Takaful Officer). Untuk KOPKAR (Koprasi Karyawan) pemasarannya berlokasikan di wilayah Jakarta sedangkan AO (Aliance Takaful Officer) berada di Luar Jakarta.

Pada kenyataannya, seluruh agen dan karyawan pun boleh menjual produk fulPROTEK tanpa ada batas karena, produk fulPROTEK tersebut di buat secara khusus dalam bentuk paket, yang mana didalam paket tersebut berisikan :

a) Starter Pac lengkap (Kartu, PIN, TIN, buku petunjuk Shar-e / ringkasan syarat-syarat umum dan khusus polis fulPROTEK)

b) Formulir Aplikasi

c) Slip Setoran perdana

\section{Promosi (Promotion)}

Promosi mencerminkan kegiatan-kegiatan yang mengkomunikasikan ke unggulan produk dan membujuk konsumen agar mereka mau membelinya. Dalam melakukan promosi produk fulPROTEK, PT. Asuransi Takaful Keluarga menggunakan media periklanan, seperti media masa (Koran), internet, penjualan, brosur-brosur, dan publikasi. Karena promosi sangat berhubungan erat dengan komunikasi. PT. Asuransi Takaful Keluarga juga menggunakan sistem perseorangan (personal selling), terhadap penjualan produk asuransinya, alasan dalam menggunakan personal selling adalah karena sistem ini dianggap sistem yang paling berhasil dalam proses pemasaran produk.

\section{Analisis SWOT Strategi Pemasaran Produk fulPROTEK}

Analisis SWOT adalah indentifikasi berbagai faktor secara sistematis untuk merumuskan strategi perusahaan. Analisis ini didasarkan pada logika yang dapat memaksimalkan kekuatan (Strengths), Peluang (Opportunities), namun secara bersamaan dapat meminimalkan kelemahan (Weaknesses), dan ancaman (Threats).

Penelitian menunjukkan bahwa kinerja perusahaan dapat ditentukan oleh kombinasi faktor internal dan eksternal. Kedua faktor tersebut harus di pertimbangkan dalam analisis SWOT. SWOT adalah Internal Strenghts dan Weaknesses serta lingkungan eksternal Opportunities dan Threats yang dihadapi dunia bisnis. 
Kinerja perusahaan dapat ditentukan dengan analisis SWOT, yang merupakan hasil perbandingan dengan faktor eksternal (peluang dan ancaman / tantangan). Faktor internal diperoleh dari data dalam lingkungan perusahaan, seperti dari laporan keuangan (neraca L/R, cashflow dll), kegiatan operasional, kegiatan pemasaran dan data staf karyawan. Sedangkan faktor eksternal diperoleh dari data lingkungan di luar perusahaan, seperti dari analisis pasar, analisis kompetitor, analisis komunitas, analisis pemasok, analisis pemerintah dan analisis kelompok (untuk kepentingan tertentu).

Maksud dan tujuan dari analisis SWOT adalah untuk meneliti dan menentukan dalam hal manakah "lembaga" Kuat sehingga dapat dioptimalkan, Lemah sehingga dapat segera dibenahi, Kesempatan-kesempatan atau Peluang untuk dapat dimanfaatkan dan Ancaman-ancaman dari luar untuk dapat diantisipasi.

MATRIK SWOT

\begin{tabular}{|c|c|c|}
\hline IFAS & $\begin{array}{c}\text { Strenght } \\
\text { (Kekuatan) }\end{array}$ & $\begin{array}{l}\text { Weaknesses } \\
\text { (Kelemahan) }\end{array}$ \\
\hline $\begin{array}{l}\text { Opportunities } \\
\text { (Peluang) }\end{array}$ & $\begin{array}{l}\text { Strategi SO } \\
\text { (Agresif) }\end{array}$ & $\begin{array}{c}\text { Strategi WO } \\
\text { (Turn-around) }\end{array}$ \\
\hline $\begin{array}{l}\text { Threaths } \\
\text { (Ancaman) }\end{array}$ & $\begin{array}{c}\text { Strategi ST } \\
\text { (Difersifikasi) }\end{array}$ & $\begin{array}{l}\text { Strategi WT } \\
\text { (Defensif) }\end{array}$ \\
\hline
\end{tabular}

IFAS adalah internalstrategic factors analysis summary, yaitu faktorfaktor strategis internal suatu perusahaan. EFAS adalah external strategic factor analysis summary, yaitu faktor-faktor strategi eksternal perusahaan. Keduanya dibandingkan yang dapat menghasilkan alternatif strategi (SO, ST, WO, WT) pada kuadran 1-4, yaitu:

Strategi SO = Kuadran 1

Ini merupakan situasi yang sangat penting menguntungkan. Perusaha an tersebut memiliki peluang dan kekuatan, sehingga dapat memanfaatkan peluang sebesar-besarnya. Strategi yang harus diterapkan dalam kondisi ini adalah mendukung kebijakan pertumbuhan yang agresif (Growth Oriented Strategy).

Strategi ST = Kuadran 2

Ini adalah strategi dalam menggunakan kekuatan yang dimiliki pe rusaha an untuk mengatasi ancaman. Strategi ini dipakai untuk me manfaatkan peluang jangka panjang dengan cara strategi diversifikasi ( produk/pasar ).

Strategi WO = Kuadran 3 


\section{VISA: Journal of Visions and Ideas}

\section{Vol 1 No 3 (2021) 248-260 E-ISSN 2809-2058 P-ISSN 2809-2643 DOI: 47467/visa.v1i3.794}

Strategi ini diterapkan berdasarkan pemanfaatan peluang yang ada dengan cara meminimalkan kelemahan yang ada. Perusahaan menghadapi peluang pasar yang sangat besar, tetapi di lain pihak harus menghadapi beberapa kendala / kelemahan internal. Cara yang efektif adalah dengan peninjauan kembali teknologi yang digunakan untuk atau dengan menawarkan produk-produk baru.

Strategi WT = Kuadran 4

Strategi ini merupakan situasi yang sangat tidak menguntungkan. Dimana perusahaan harus menghadapi berbagai ancaman dan kelemahan internal. Kegiatan ini bersifat defensif dan berusaha meminimalkan kelemahan yang ada serta menghindari ancaman.

\section{Kekuatan (Strenght) Strategi Pemasaran Produk fulPROTEK}

\section{a. Citra Perusahaan yang baik.}

Perusahaan Asuransi Takaful dikenal sebagai perusahaan asuransi syariah pertama kali yang menggunakan aplikasi sistem syariah di dalam mengoprasikan dananya. Hal ini dapat dilihat dari banyaknya anak cabang yang telah beroprasi di seluruh Indonesia dan juga sebagai contoh bagi perusahaan-perusahaan asuransi konvensional yang membuka cabang syariah.

Sampai saat ini citra Perusahaan Asuransi Takaful Keluarga sudah tidak diragukan lagi selain itu, atas upaya keras seluruh jajaran perusahaan, Asuransi Takaful Keluarga meraih MUI Award 2004 sebagai Asuransi Syariah terbaik di Indonesia. Dan memperoleh sertifikasi ISO 9001:2000 dari Det Norske Veritas (DNV), di Belanda pada April 2004.

\section{b. Menggunakan jasa Perbankan didalam memasarkan produk}

Untuk sebuah perusahaan asuransi strategi pemasaran merupakan masalah yang urgen. Dalam memasarkan produk asuransi jasa bank sangat di perlukan karena selain adanya kerjasama yang terjalin antara bank dan asuransi nasabah juga mendapat pelayanan jasa tabungan sekaligus proteksi perlindungan dari asuransi.

\section{c. Memberikan kemudahan berakses kepada nasabah}

Dengan memiliki produk ini nasabah bisa melakukan transaksi di lebih dari 18.000 merchant, diseluruh Indonesia.

\section{d. Sistem personal selling merupakan cara yang paling efektif yang digunakan}

Sistem personal selling atau agency merupakan salah satu kekuatan dari sistem pemasaran, besarnya kekuatan dan pengaruh agen dalam penjualan produk asuransi juga diperkuat oleh survei yang dilakukan LIMRA (Life Insurance Marketing and Research Assosiation) Amerika. Berdasarkan hasil survei yang dilakukan lembaga tersebut terungkap bahwa sekitar 90\% premi asuransi diseluruh 


\section{VISA: Journal of Visions and Ideas}

\section{Vol 1 No 3 (2021) 248-260 E-ISSN 2809-2058 P-ISSN 2809-2643 DOI: 47467/visa.v1i3.794}

dunia dihasilkan oleh agen. Temuan ini menunjukkan bahwa kehebatan agen dalam menjual produk asuransi memang belum bisa disaingi oleh jalur distribusi lainnya.

\section{e. Memiliki agen yang mempunyai integritas tinggi}

PT. Asuransi Takaful Keluarga memiliki agen yang menjunjung tinggi nilai moral dan profesi secara profesional, memiliki sikap pantang menyerah dalam mencari nasabah serta harus mencerminkan nilai-nilai keislaman seperti jujur dan amanah.

Agen yang juga sebagai penasihat keuangan (Financial Advisor) memiliki tanggung jawab untuk memberikan usulan dan saran kepada calon nasabahnya untuk menginvestasikan uang yang calon nasabah miliki kepada suatu instrumen investasi, selain itu agen juga mengungkapkan secara terbuka fakta-fakta yang berhubungan dengan transaksi dan juga tidak bersifat memaksakan

\section{Kelemahan (Weakness) Strategi Pemasaran Produk fulPROTEK}

a. Kurangnya pemahaman masyarakat tentang produk asuransi syariah Karena minimnya publikasi dan sosialisasi tentang ekonomi Islam, termasuk juga asuransi syariah sebagai bagian dari ekonomi Islam itu sendiri kepada masyarakat luas, mengakibatkan hanya sebagian kecil masyarakat yang mengetahui tentang keberadaan dan petingnya lembaga asuransi syariah.

b. Promosi yang dilakukan belum menyeluruh terhadap masyarakat Promosi terhadap suatu produk dinilai sangat sangat penting bagi pemasar an produk tersebut, jika dilakukan secara besar-besaran kemungkinan besar produk tersebut dikenal oleh masyarakat luas dan kemungkinan masyarakat untuk membeli produk tersebut semakin besar.

c. Penyebaran brosur kurang maksimal

Dilihat dari bentuknya, brosur merupakan sarana yang sangat penting dan praktis dalam suatu pemasaran produk, dimana calon nasabah akan dengan mudah mengetahui informasi tentang suatu produk. Namun yang terjadi dilapangan, penyebaran brosur tidak sepenuhnya maksimal, brosur hanya diberikan kepada calon nasabahnya saja, bukan masyarakat secara luas. Jadi efektifitas brosur masih belum maksimal dilakukan sebagai suatu alat pemasaran produk.

d. Produk yang belum familiar

Kebanyakan masyarakat luas mengetahui bahwa asuransi hanya sebagai perlindungan jiwa saja, dan menganggap sama saja seperti produk asuransi yang lainnya. Padahal dalam hal ini nasabah akan mendapatkan dua keuntungan sekaligus selain nasabah bisa menabung juga mendapatkan proteksi asuransi.

\section{Peluang (Opportunities) Strategi Pemasaran produk fulPROTEK}




\section{VISA: Journal of Visions and Ideas}

\section{Vol 1 No 3 (2021) 248-260 E-ISSN 2809-2058 P-ISSN 2809-2643 DOI: 47467/visa.v1i3.794}

\section{a. Fatwa MUI tentang Bunga Bank Haram}

Dengan dikeluarkannya fatwa MUI bahwa "Bunga Bank Haram", diharapkan semua masyarakat beralih kepada lembaga-lembaga keuangan syariah walaupun tidak semua masyarakat Indonesia tertarik dalam hal ini, namun paling tidak ini akan menjadi sebuah peluang besar terhadap perkembangan syariah.

b. Masyarakat Indonesia yang mayoritas muslim

Dengan adanya Fatwa MUI yang menyebutkan "Bunga Bank Haram" maka ini akan menjadi peluang baik bagi lembaga keuangan syariah, dimana masyarakat Indonesia yang mayoritas muslim berindikasi untuk lebih memilih lembaga keuangan yang berbasis syariah guna menghindari riba.

c. Banyaknya Bank-bank syariah dan konvensional yang membuka divisi syariah

Seiring meningkatnya pertumbuhan bank syariah, kebutuhan akan asuransi syariah pun meningkat, karena dalam operasionalnya bank syariah akan membutuhkan asuransi syariah untuk meng-cover resiko yang akan timbul dari transaksi-transaksi perbankan seperti, kemacetan kredit dan investasi, hingga resiko yang timbul dari inventaris-inventaris yang mereka miliki.

d. Banyaknya media massa yang beroperasi dan beredar

Bertambah banyaknya media massa yang ada di Indonesia khususnya, baik itu media elektronik maupun media cetak dapat dijadikan suatu ajang promosi dan publikasi PT. Asuransi Takaful Keluarga agar produk yang dihasilkannya dapat dikenal secara luas oleh masyarakat.

\section{e. Dukungan Pemerintah}

Dalam melakukan operasionalnya lembaga keuangan syariah sangat memerlukan dukungan dari pemerintah karena, sistem perekonomian pertama di Indonesia adalah lembaga keuangan.

\section{Ancaman (Threath) Strategi Pemasaran Produk fulPROTEK}

a. Adanya Perusahaan yang memiliki produk yang sejenis

Banyak bermunculannya perusahaan asuransi yang juga melahirkan produk yang sejenis, meskipun berbeda dalam konsep,dikhawatirkan ini akan menghambat perkembangan produk fulPROTEK.

b. Tingginya tingkat persaingan antar lembaga keuangan syariah 


\section{VISA: Journal of Visions and Ideas}

\section{Vol 1 No 3 (2021) 248-260 E-ISSN 2809-2058 P-ISSN 2809-2643 DOI: 47467/visa.v1i3.794}

Saat ini lembaga keuangan syariah mengalami pertumbuhan yang pesat, maka berimplikasi pada tingginya tingkat persaingan yang terjadi antar sesama lembaga. Setiap lembaga akan berlomba untuk me menangi persaingan tersebut dengan berbagai cara, mulai dari peluncuran produk-produk baru dengan manfaat yang besar dengan tarif premi yang kecil hingga perbaikan pelayanan. Untuk itu perusahaan Asuransi Takaful Keluarga harus memiliki strategi-stretegi dalam upaya manghadapi persaingan antar lembaga keuangan khusus nya Asuransi Syariah.

c. Minimnya pemahaman dan pengetahuan masyarakat tentang asuransi syariah

Karena minimnya publikasi dan sosialisasi tentang ekonomi Islam, termasuk juga asuransi syariah sebagai bagian dari ekonomi Islam itu sendiri kepada masyarakat luas, mengakibatkan hanya sebagian kecil masyarakat yang mengetahui tentang keberadaan dan petingnya lembaga asuransi syariah.

d. Tingginya tingkat persaingan harga produk

Perusahaan dapat memperoleh keunggulan bersaing lebih tinggi dibandingkan dengan pesaingnya jika dia dapat memberikan harga jual yang lebih murah dari pada harga yang diberikan oleh pesaingnya dengan nilai/kualitas produk yang sama. Harga jual lebih rendah dapat dicapai oleh perusahaan tersebut karena dia memanfaatkan skala ekonomis, efisiensi produksi, penggunaan teknologi, kemudahaan akses dengan bahan baku, dan sebagainya.

Setelah semua faktor internal (kakuatan dan kelemahan) dan eksternal (peluang dan ancaman) perusahaan diketahui langkah selanjut nya adalah dengan menentukan alternatif strategi yang dapat digunakan oleh PT. Asuransi Takaful Keluarga untuk memasarkan produknya dengan matrik SWOT.

\section{Strategi So}

Strategi ini dibuat berdasarkan jalan pikiran perusahaan, yaitu dengan memanfaatkan kekuatan untuk merebut dan memanfaatkan seluruh peluang se besar-besarnya. Setelah melihat kekuatan berupa Citra perusahaan yang baik, menggunakan jasa Perbankan didalam memasarkan produk, memberikan kemudahan berakses kepada nasabah, sistem personal selling merupakan cara paling efektif yang digunakan dan memiliki agen yang mempunyai integritas tinggi. Peluang berupa Fatwa MUI tentang bunga bank haram, masyarakat Indonesia yang mayoritas muslim, Banyaknya bankbank syariah dan konvensional yang membuka divisi syariah, Banyaknya media massa yang beroperasi dan beredar dan Dukungan dari Pemerintah.

Perusahaan Asuransi Takaful Keluarga dapat meningkatkan kerjasama dengan lembaga keuangan dan perusahaan lain, hal ini dapat dilihat dengan banyaknya bank-bank konvensional yang membuka divisi syariah serta menggunakan media massa sebagai media promosi, serta menambah dan memaksimalkan media massa yang ada dengan memperbanyak iklan. 


\section{VISA: Journal of Visions and Ideas}

\section{Vol 1 No 3 (2021) 248-260 E-ISSN 2809-2058 P-ISSN 2809-2643 DOI: 47467/visa.v1i3.794}

\section{Strategi ST}

Setelah melihat kekuatan berupa Citra perusahaan yang baik, menggunakan jasa perbankan didalam memasarkan produk, memberikan kemudahan berakses kepada nasabah, sistem personal selling merupakan cara paling efektif yang digunakan dan memiliki agen yang mempunyai integritas tinggi. Dan melihat ancaman berupa adanya perusahaan yang memiliki produk sejenis, tingginya tingkat persaingan antar lembaga keuangan syariah, minimnya pemahaman dan pengetahuan masyarakat tentang asuransi syariah, dan tingginya tingkat persaingan harga produk.

Maka Perusahaan Asuransi Takaful Keluarga mengatasi kondisi ini dengan menjaga kualitas dan mutu produk fulPROTEK, meningkat kan pelatihan dan keahlian terhadap agen, memahami kebutuhan dan keinginan pasar (nasabah), identifikasi strategi pesaing serta differensiasi produk.

\section{Penutup}

Produk fulPROTEK merupakan produk cobranding antara PT. Asuransi Takaful Keluarga dan PT. Bank Muamalat Indonesia Tbk. Dimana padaproduk tersebut terbagi menjadi 3 pilihan seri, yang masing-masing memiliki ketentuan harga dan manfaat yang akan diperoleh bagi calon nasabahnya antara lain sebagai berikut :

Seri 175, dengan harga perdana Rp. 175.000,- manfaat yang akan didapat :

* Saldo awal tabungan Rp. 100.000,-

* Bila meninggal karena kecelakaan Rp. 25.000.000,-

* Cacat tetap karena kecelakaan, makimum Rp. 5.000.000,-

* Biaya perawatan karena kecelakaan, maksimum Rp. 1.250.000,perkecelakaan

* Meninggal dunia biasa (bukan akibat kecelakaan) Rp. 5.000.000,-

Seri 275, dengan harga perdana Rp. 275.000,- manfaat yang akan didapat :

* Saldo awal tabungan Rp. 100.000,-

* Bila meninggal karena kecelakaan Rp. 100.000.000,-

* Cacat tetap karena kecelakaan, makimum Rp. 8.000.000,-

* Biaya perawatan karena kecelakaan, maksimum Rp. 5.000.000,perkecelakaan

* Meninggal dunia biasa (bukan akibat kecelakaan) Rp. 8.000.000,-

Seri 750, dengan harga perdana Rp. 750.000,- manfaat yang akan didapat :

Saldo awal tabungan Rp. 500.000,-

* Bila meninggal karena kecelakaan Rp. 100.000.000,-

- Cacat tetap karena kecelakaan, makimum Rp. 20.000.000,-

* Biaya perawatan karena kecelakaan, maksimum Rp. 5.000.000,perkecelakaan 


\section{VISA: Journal of Visions and Ideas}

\section{Vol 1 No 3 (2021) 248-260 E-ISSN 2809-2058 P-ISSN 2809-2643 DOI: 47467/visa.v1i3.794}

* Meninggal dunia biasa (bukan akibat kecelakaan) Rp. 20.000.000,-

Dalam pemasarannya menggunakan bauran pemasaran (marketing mix) yang terdiri dari produk, (Product), Harga (Price), Tempat (Place), dan Promosi (Promotion).

Kekuatan (strength) dari Strategi Pemasaran PT. Asuransi Takaful Keluarga yaitu disamping memiliki Citra Perusahaan yang baik, di dalam memasarkan produknya menggunakan jasa perbankan yang mana hal ini dilakukan agar masyarakat luas dapat mengenal produk-produk Asuransi Takaful. Disamping itu, nasabah dalam menggunakan produknya juga mendapatkan pelayanan jasa tabungan sekaligus proteksi perlindungan dari asuransi. Memberikan kemudahan dalam bertransakasi dengan tarik tunai bebas biaya di lebih dari 8.888 ATM Muamalat, BCA, dan ATM bersama di seluruh Indonesia, akses debit di lebih dari 18.000 marchant, system personal selling merupakan cara yang paling efektif yang digunakan, memiliki agen yang berintegritas tinggi. Kelemahannya (weakness): kurangnya pemahaman masyarakat tentang prouk-produk asuransi syariah, promosi yang dilakukan belum menyeluruh, terhadap masyarakat, penyebaran brosur kurang maksimal, produk yang belum familiar. Peluang (opportunity): fatwa MUI tentang bunga bank haram, masyarakat Indonesia yang mayoritas muslim, banyaknya bank-bank konvensional yang membuka devisi syariah, banyaknya media massa yang beroperasi dan beredar, dukungan dari pemerintah. Tantangan (threats): adanya perusahaan yang memiliki produk sejenis, tingginya tingkat persaingan antar lembaga keuangan syariah, minim nya pemahaman dan pengetahuan masyarakat tentang asuransi syariah, dan tingginya tingkat persaingan harga produk.

Perkembangan pemasaran produk fulPROTEK dari awal hingga kini sudah mencapai $2 \%$ hal ini berpengaruh terhadap pendapatan premi perusahaan. dengan jumlah nasabah yang ada pada tahun 2006 sebanyak 14.886 nasabah, 2007 bertambah 15.830 nasabah dan 2008 sejumlah 10.234 .

\section{DAFTAR PUSTAKA}

Abdul Kadir, Muhammad, Hukum Asuransi Indonesia, Bandung: PT. Citra Aditya Bakti, 1991.

Ali, AM. Hasan, Asuransi dalam Perspektif Hukum Islam (Suatu Tinjauan Analisis Historis, Teoritis \& Praktis), Jakarta, Kencana, 2004, Cet-1

Amrin, Abdullah Strategi Pemasaran Asuransi Syariah, Jakarta: PT. Gramedia Widiasarana Indonesia, 2007.

Artikel, Bancassurance. Ditinjau dari Perspektif Asuransi, Jakarta: Proteksi, Maret, 1999. 


\section{VISA: Journal of Visions and Ideas}

\section{Vol 1 No 3 (2021) 248-260 E-ISSN 2809-2058 P-ISSN 2809-2643 DOI: 47467/visa.v1i3.794}

Boyd, Walker, Larreche, Manajemen Pemasaran (suatu pendekatan strategi dengan orientasi global) Jakarta: Penerbit Erlangga, 2000, edisi ke-2.

Kotler Philip dan N. Bloom, Paul. Teknik dan Strategi Pemasaran Jasa Profesional, Jakarta: Intermedia, 1995.

Kasmir, Manajemen Perbankan, Jakarta: PT. Raja Grafindo Persada, 2003, Edisi 1.

Kartajaya. Hermawan dan Sula, Muhammad Syakir. Syariah Marketing, Jakarta: Mizan, 2006, Cet.II.

Lamb, Jr, Charles W. Dkk. Penerjemah: David Octarevia, PEMASARAN, Jakarta: PT. Salemba Empat Petria, 2001, Cet. 1.

Lupiyodi, Rambat. Manajemen pemasaran Jasa: Teori dan Praktek, Jakarta: Salemba Empat, 2000.

Nashirudin Al-Albani, Muhammad, Mukhtashar shahih muslim (Ringkasan Shahih Muslim). Jakarta: PT. Pustaka Azzam

Peter, Salim dan Yenny, Salim, Kamus Bahasa Indonesia Kontemporer, h. 1463.

PKES (Pusat Komunikasi Ekonomi Syariah), Buku Saku Lembaga Bisnis Syariah+), Jakarta, Gd. Arthaloka Gf-05 Jl. Jend. Sudirman Kav.2.

Majalah, Proteksi, edisi XXV, Mei 2005.

Rangkuti, Freddy. Analisis SWOT Teknik Membedah Kasus Bisnis, Jakarta: PT Gramedia Pustaka Utama, Juli 2006, Cet Ke-14.

Salim, Peter dan Yenny, Salim. Kamus Bahasa Indonesia Kontemporer, h. 1463.

Simamora, Bilson. Memenangkan Pasar dengan Pemasaran Efektif dan Profitabel, Jakarta: PT. Gramedia Pustaka Utama, 2001.

Stanton, J. William. Prinsipprinsip Pemasaran, Jakarta: Erlangga, 1994.

Subana, Muhammad dan Sudrajat. Dasardasar Penelitian Ilmiah, Bandung: Pustaka Setia, 2001.

Sudarsono, Heri. Bank dan Lembaga Keuangan syariah, Jakarta: PT. EKONOSIA, UII Yogyakarta, Edisi 2.

Sula, Muhammad Syakir. Asuransi Syariah (Life And General) Konsep dan Sistem Operasional, Jakarta: Gema Insani Press, 2004, Cet.I

Suma, Muhammad Amin. Asuransi Syariah dan Asuransi Konvensional, Jakarta: Kholam Publishing, 2006.

Tim Penulis Fakultas Syariah dan Hukum, Pedoman Penulisan Skripsi, Jakarta, Fakultas Syariah dan Hukum UIN Syarif Hidayatullah.

Tjiptono, Fandy. Strategi Pemasaran, Yogyakarta: Andi Press, 2001, Cet. Ke-5. 


\section{VISA: Journal of Visions and Ideas}

Vol 1 No 3 (2021) 248-260 E-ISSN 2809-2058 P-ISSN 2809-2643 DOI: 47467/visa.v1i3.794

http://www.muamalatbank.com

http://www.takaful.com 